\title{
THE CHALLENGE OF PENSION REFORM IN GEORGIA: NON-CONTRIBUTORY PENSIONS AND ELDERLY POVERTY
}

\author{
Tamila Nutsubidze \\ CRR WP 2015-18 \\ July 2015
}

\author{
Center for Retirement Research at Boston College \\ Hovey House \\ 140 Commonwealth Avenue \\ Chestnut Hill, MA 02467 \\ Tel: 617-552-1762 Fax: 617-552-0191 \\ http://crr.bc.edu
}

Tamila Nutsubidze is Fulbright Visiting Scholar at the Center for Retirement Research at Boston College (CRR). The research reported herein was pursuant to a grant from the Fulbright Visiting Scholar Program, which is funded by the U.S. Department of State's Bureau of Education and Cultural Affairs. The results presented here are based on the data available at the time of writing. The findings and conclusions expressed are solely those of the author and do not represent the views of any Georgian government or international agency, the U.S. Department of State's Bureau of Education and Cultural Affairs, or Boston College. The author would like to thank Alicia H. Munnell, Anthony Webb, and Mauricio Soto for comments. She also thanks the staff members of the CRR, the Budget and Finance Committee of the Parliament of Georgia, the Social Service Agency of Georgia, the Pension Reform Unit of the Ministry of Economy and Sustainable Development of Georgia, and the National Statistics Office of Georgia for providing helpful discussions, data, and information.

(C) 2015, Tamila Nutsubidze. All rights reserved. Short sections of text, not to exceed two paragraphs, may be quoted without explicit permission provided that full credit, including $@$ notice, is given to the source. 


\begin{abstract}
About the Center for Retirement Research
The Center for Retirement Research at Boston College, part of a consortium that includes parallel centers at the University of Michigan and the National Bureau of Economic Research, was established in 1998 through a grant from the Social Security Administration. The Center's mission is to produce first-class research and forge a strong link between the academic community and decision-makers in the public and private sectors around an issue of critical importance to the nation's future. To achieve this mission, the Center sponsors a wide variety of research projects, transmits new findings to a broad audience, trains new scholars, and broadens access to valuable data sources.
\end{abstract}

Center for Retirement Research at Boston College

Hovey House

140 Commonwealth Ave

Chestnut Hill, MA 02467

Tel: 617-552-1762 Fax: 617-552-0191

http://crr.bc.edu

Affiliated Institutions:

The Brookings Institution

Massachusetts Institute of Technology

Syracuse University

Urban Institute 


\section{Abstract}

Georgia, a country characterized by an aging population with a high incidence of poverty and limited public financial resources, offers virtually complete non-contributory basic pension coverage. The basic pension has, to date, proved effective in dealing with poverty arising from political instability, military conflicts, economic deterioration, transition to a market economy, emigration of its younger population, and aging. But Georgia's fiscal constraints and aging population also highlight the importance of developing and improving the pension system, in order to ensure its sustainability.

Since 2012 the Georgian government has put forth a systemic reform proposal - a compulsory pension insurance - including the implementation of contributory pension schemes to supplement the basic non-contributory pension. While the proposal is a promising start, it alone would not be enough to ensure that the government's fiscal burden remains reasonable, while maintaining the basic pension system's long-term adequacy and flexibility to adapt to the evolving demographic environment. This paper presents policy reform choices, which suggest that, in Georgia, pension reform might also include increasing statutory retirement ages and reducing the generosity of benefits through means testing. These policy reform options would involve difficult tradeoffs, which are also described in this paper.

Although the paper focuses on the Georgian non-contributory basic pension, its poverty reduction effect and policy reform options, the case of the Georgian non-contributory basic pension might hold value for some low- and middle-income countries that are considering implementation or expanding coverage of non-contributory pensions. 


\section{Introduction}

As in many low- and middle-income countries, the provisions of an adequate old-age income, which includes mitigating poverty among the elderly and their households, is a major challenge in Georgia. ${ }^{1}$

In 2006, Georgia introduced its basic non-contributory pension, which is financed with tax revenues. ${ }^{2}$ The impetus for implementation of the basic pension was the collapse of the Soviet Union. Dramatic changes in the country - economic deterioration provoked by the decline in industrial and agricultural production, a challenging transition to a market economy, military conflicts, rising informal sector, migration of younger population, and aging - caused a high incidence of poverty that had to be addressed by social policy.

The non-contributory basic pension has proved effective in dealing with elderly, household and child poverty in Georgia. However, two dimensions of the non-contributory pension limit its potential sustainability: the country's aging population and scarce public financial resources, both of which create many other pressing needs in social provision, including social assistance and health care.

Since 2012, the Georgian government has put forth a systemic reform proposal - a compulsory pension insurance - including the implementation of contributory pension schemes to supplement the basic non-contributory pension (Government Program: For Strong, Democratic and Unified Georgia (2012; 2013; 2014; 2015); Country Basic Data and Directions (2012-2015; 2013-2016; 2014-2017; 2015-2018); Social-Economic Development Strategy of Georgia, Georgia 2020; The Law of Georgia on State Budget (2013; 2014; 2015)).

While the proposed reform is a promising start, it alone would not be enough to ensure that the government's fiscal burden remains reasonable, while maintaining the basic

\footnotetext{
${ }^{1}$ Economic literature suggests that many middle-income countries (Brazil, Chile, Mauritius, and South Africa) face the challenge of improving sustainability in their pension systems, while low-income countries, with younger populations (Bangladesh, Bolivia, and Lesotho) lack adequate coverage for their elderly (Holzmann, Robalino, and Takayama 2009). Additionally, emerging European countries face the dual challenges of improving the sustainability of its pension systems while maintaining adequacy (Clements, Eich, and Gupta 2014). Georgia is among the lower-middle-income countries with gross national income per capita of 7,040 (PPP, current international dollars, 2013) (World Bank 2015a).

2 The term "basic pension" derives from the World Bank's widely accepted, multipillar pension taxonomy. The World Bank’s pension policy framework flexibly applies five-pillar model defining the range of design elements to determine the pension system modalities and reform options that should be considered. The five pillars are: a non-contributory "zero pillar," a mandatory "first pillar," a mandatory "second pillar," a voluntary "third pillar," and a non-financial "fourth pillar" (Holzmann, Hinz, and Dorfman 2008). This structure is an expansion of the World Bank's original concept of a specific three-pillar pension structure to include two additional pillars: the basic (zero) pillar and non-financial fourth pillar. Additionally, the basic (zero) pillar deals more explicitly with the poverty objective (Holzmann and Hinz 2005).
} 
pension system's long-term adequacy and creating a system with sufficient flexibility to adapt to the evolving demographic environment.

This paper presents policy reform choices, which suggest that in Georgia, pension reform might also include increasing statutory retirement ages and reducing the generosity of benefits through means testing. These policy reform options would involve difficult tradeoffs, which are also described in this paper.

Given rising international interest in non-contributory pensions - particularly during the last two decades - this paper might contribute to the economic literature by describing these pensions, their effect in alleviating poverty, and reforms associated with them. Additionally, this paper might hold value for some low- and middle-income countries that are considering implementation or expanding coverage of non-contributory pensions. It is worth mentioning that Palacios and Knox-Vydmanov (2014) suggest that most pensions in Central Asian and Eastern European countries have a distinct nature that reflects the Soviet history of their pension systems. Specifically, they have nearly universal pension systems based on payroll contributions, and non-contributory pensions are often limited to a tiny minority of population (for example, in Kyrgyzstan and Moldova, fewer than 2 percent of population over age 60 receives a non-contributory pension). Palacios and Knox-Vydmanov (2014) highlight that the proportion of the workforce in the region contributing to a pension is rapidly decreasing and suggest that non-contributory pensions will become increasingly important if those countries are to maintain universal coverage in their pension systems. ${ }^{3}$ The methodological approach in this research paper involves a detailed understanding of the implementation, structure, scope, and administration of the non-contributory basic pension in Georgia. Research involved collecting and collating country information, qualitative and quantitative data analysis, and interviews. Projected pension spending was calculated based on the most recent available pension spending data (2014) from the Social Service Agency of Georgia, demographic data from the United Nations and Social Service Agency of Georgia, and labor force data from the International Labor Organization (ILO).

More specifically, the basic pension spending projections use a simple model that takes into account the evolution of demographics provided in the United Nations Population Prospects. The model relies on an identity, whereas pension spending as percent of the gross domestic product (GDP) is equal to the product of the old age dependency ratio (the ratio of

\footnotetext{
${ }^{3}$ Palacios and Knox-Vydmanov (2014) point out that Georgia is one country that appears to have already recognized this trend by converting its contributory social insurance system into a basic universal noncontributory pension in 2006.
} 
population age 60 and older to population age 15-59); the coverage ratio (the ratio of the number of pensioners to the population age 60 and over); the benefit ratio (the ratio of the average benefit as percent of GDP per worker); and the inverse of the employment to population ratio for ages 15-59 (employment is assumed to follow labor force participation and it is obtained from the ILO).

In the baseline pension spending projection, it is assumed that the coverage and benefit ratio remain roughly constant (pensioners are projected to grow in line with the old-age population, age 60 and older for men and age 55 and older for women), the employment to population ratio increases slightly, and thus the largely reflect the projected evolution of the old-age dependency ratio. In this basic model, changes in the retirement age affect the coverage ratio - it is assumed that a one-year increase in the retirement age reduces the number of pensioners by the share of the old-age population in that given age. For example, increasing the retirement age for men from age 60 to 61 reduces the number of pensioners by the share of men age 60 in all men age 60 and older. In addition, it is assumed that about half of those for whom the retirement age increases would remain in the labor force, thus having an impact on employment. Changes in benefits (indexation or reductions) affect the benefit ratio, and changes in beneficiaries affect the coverage ratio.

The remainder of this paper is structured as follows. Section 2 presents a discussion of the importance of the non-contributory basic pensions in reducing poverty in Georgia. This includes a brief discussion of the social, economic and demographic conditions surrounding the formation of the non-contributory basic pension and its role and scope in poverty alleviation. Section 3 examines the current retirement income landscape in Georgia and identifies fiscal constraints related to the basic pension system. Section 4 presents demographic and basic pension spending projections. Section 5 discusses further reform options that could address fiscal and demographic challenges consistent with the need to maintain the sustainability and adequacy of the non-contributory basic pension system in the country. Section 6 offers some critical considerations and conclusions about the pension reform options available to Georgia.

\section{The Importance of Non-Contributory Pensions on Reducing Poverty}

Formation and Development of the Non-Contributory Pension System in Georgia

One of the most substantial challenges Georgia faced during the transition to democracy and a free-market economy in the mid-1990s was reforming its public welfare and 
social security system inherited from the Soviet regime. ${ }^{4}$ The foundation of the Communist welfare and social security system was a guarantee of full employment.

The Georgian-Soviet public pension system provided differentiated pensions to retirees based on occupation. Pension benefits were financed on a pay-as-you-go basis through the transfer of funds from state-owned enterprises to the local Georgian department of the Soviet state insurance company, Gosstrakh. To receive a pension, older women were required to have worked a minimum of 20 years, and older men a minimum of 25 years (Gugushvili 2009). In the late 1980s, old-age pension coverage reached nearly a universal level, paying between 60 percent and 100 percent of the average wage in Georgia (Buckley 1998).

Because of the demise of the Soviet Union in 1991, the new Georgia had to reinvent its pension system, and Georgia faced substantial obstacles along the way from economic and demographic circumstances. The economic profile of the early 1990s was typical for countries shifting from a centrally-planned to free-market economy (Baumann 2012). Dramatic hyperinflation and currency depreciation (1993-1994), sharp economic decline and stagnation, and a state budget deficit throughout the 1990s and into the early 2000s affected Georgia's ability to keep up with pensioners' expectations. ${ }^{5}$ The bad economic situation in the country was made worse by demographic and social conditions: the size of the population shrunk, birth rates were dropped, participation in the labor force declined, wages plummeted, and unemployment rose. Meanwhile, the informal sector grew and rampant external migration left behind an aging population (de Castello Branco 1996; de Castello Branco 1998; Jian-Ye Wang 1999; National Bank of Georgia 2001; European Initiative - Liberal Academy Tbilisi 2012).

By 1996, the government had eliminated the Soviet system of differentiated pensions, based on occupation, and replaced it with a flat-rate pension system. These parametric adjustments introduced eligibility for pension benefits only for those who had previously contributed to the system. ${ }^{6}$ Pension payments were low and what payments existed were delayed for months and years due to budget limitations (European Initiative - Liberal Academy Tbilisi 2012). More than a decade after the country’s independence (2004),

\footnotetext{
${ }^{4}$ In Georgia, as in part of the Soviet Union, retirement security pay-as-you-go system was in effect since 1920s (Economic Policy Research Center 2013).

5 “State budget" is Georgia's central government's budget.

6 "Pension benefits were determined by the following way: the number of those formally employed in the population was multiplied by the average salary and tax tariff, and then revenues were divided by the number of pensioners. This meant that equal pensions were granted to all retirees regardless of their salaries during employment, length of service, or differences in pension type (Gugushvili 2009)”.
} 
pension payments were only 7 percent of the (GDP) per capita (Social Service Agency 2014). Pensioners had to rely on families, relatives, and neighbors for help. They turned to begging and street trading to survive.

In 2006, the Georgian Parliament's passage of the Law of Georgia on State Pension (2005) led to the elimination of the existing pension system and the introduction of the noncontributory flat-rate basic pension, which had three components: basic old-age pension, disability pension, and survivor pension and was disbursed when citizens reached the retirement age (age 65 for men, and age 60 for women) or had a disability or loss of the breadwinner. Most importantly, in 2006 the old-age pension became universal for the elderly. Under reforms implemented in the fall of 2012, disability and survivor pensions have been separated into different social assistance programs. However, for research purposes in addition to an old-age pension, disability and survivor benefits are also considered a part of the basic pension in this research.

As mentioned, the basic pension was established as a flat-rate pension (2006), though became a differentiated pension a year later. More specifically, about 88 percent of Georgian pensioners in 2006 received a standard minimum old-age pension of 38 Georgian Lari (GEL). The rest of the pensioners, including special categories of pensioners (veterans, widowed, politically repressed people, etc.), were eligible for a higher old-age pension of GEL 43-129. However, from 2007, the old-age pension became differentiated after the introduction of the seniority increment provided on the basis of years of work. As a result, only 33 percent of pensioners (compared to 88 percent in 2006) received a minimum old-age pension, which had increased to GEL 55 in 2007, while the rest of the pensioners became eligible for an entitlement of an additional amount of GEL 2-10 disbursed based on the years of work. In 2012, the seniority increment was abolished. That same year, another change was implemented: different pensions were paid to pensioners of different ages. However, age differentiation was abolished by April 2013. More importantly - starting in September 2013 - the basic old-age pension returned to a flat-rate pension.

\section{The Non-Contributory Pension System and Poverty Trends}

Establishment of the non-contributory basic pension in 2006 was driven by the need to reduce Georgia's substantial poverty. Since the implementation of the basic pension, an old-age pension program, the basic pension system's largest component - has covered almost all the nation's elderly and supported their incomes in old age by providing a minimum 
income floor for all. The old-age average pension increased from 14.3 percent of GDP per capita in 2006 to 26.5 percent in 2013 (see Figure 1).

At the same time, the relative elderly poverty decreased significantly: poverty among the population ages 60 and over, who fall under 60 percent of median consumption, decreased from 22.4 percent in 2006 to 15.1 percent in 2013. ${ }^{7}$ Figure 2 shows the correlation between the increase in old-age pension and the reduction in relative elderly poverty in the country from 2004-2013.

In Georgia in 2013, relative elderly poverty was substantially lower than poverty among other age groups - as shown in Figure 3 - which compares poverty among the three groups of the population: children (age 0-14), the working age population (age 15-59), and the elderly (age 60+). In 2013, the relative elderly poverty was 15.1 percent, compared with 23 percent relative poverty among the working-age population that year and 25 percent poverty among children.

The evidence suggests that the old-age pension reduces poverty in Georgia. The UNICEF publication (UNICEF 2012), “Georgia: Reducing Child Poverty,” highlights the impact of old-age pension on consumption poverty in Georgia. The report shows that the old-age pension has a strong effect in reducing both relative and absolute extreme elderly, child, and household poverty, particularly for pensioners who live alone or in small households. ${ }^{8}$ Moreover, the research findings suggest that if the pension had been removed in 2011, the percentage of pensioners who live below the relative poverty threshold would have more than doubled (see Figure 4). This report shows that the old-age pension has important potential in the context of achieving Georgia's overall poverty reduction goals. It shows the redistributive and social impact of the pension.

It is worth noting that the relative elderly poverty rates in Georgia and in the European Union (EU) are comparable. The average at-risk-of-poverty rate in the EU was about 14 percent in 2013, which is comparable to the Georgian relative elderly poverty of 15.1 percent that year. ${ }^{9}$ However, on an absolute basis, Georgia’s poverty remains higher than in Europe's and Central Asia's transition economies. For instance, the World Bank

\footnotetext{
${ }^{7}$ This paper uses a relative poverty threshold equal to 60 percent of median consumption, or GEL 130.2 per month (2013) according to the National Statistics Office of Georgia.

${ }^{8}$ The UNICEF (2012) report used an absolute extreme poverty threshold: GEL 71.7 a month per adult equivalent, based upon the $\$ 1.25$ benchmark used by the World Bank (identifying extreme poverty) and reflecting 2011 prices using the CPI (UNICEF 2012).

${ }^{9}$ According to the glossary of the Statistical Office of the European Commission (Eurostat) "the at-risk-ofpoverty rate" is the share of people with an equivalised disposable income (after social transfer) below the atrisk-of-poverty threshold, which is set at 60 percent of the national median equivalised disposable income after social transfers (Eurostat 2014).
} 
Report, “The Inverting Pyramid: Pension Systems Facing Demographic Challenges in Europe and Central Asia,” shows that the percentage of all Georgian households that lived on \$2.50 a day reached approximately 50 percent of the population by the end of 2009 (Schwarz, Arias, at al. 2014). The report highlights that in 2009, Georgian households in poverty - those living on $\$ 2.50$ a day - with a pensioner (age $65^{+}$) in the household were less poor than households with pensioners who were older than 80 years and households with no pensioner (see Figure 5). The World Bank highlights that given the weaker buying power of many households in the European and Central Asian region (ECA), poverty rates are expected to rise in several oil-exporting and remittance-receiving countries (World Bank 2015b).

Given the growing interest in social pensions, mostly in the last two decades, numerous studies document their poverty reduction effects. ${ }^{10}$ Additionally, the preponderance of the existing literature identifies their beneficial effect on a variety of outcomes, from expanding coverage and achieving vertical equity.

For example, Holzmann, Robalino, and Takayama (2009) suggest that noncontributory pensions have a strong poverty reduction impact, particularly in middle-income countries where pensions can make up a significant share of different pension schemes. In most middle-income countries, dependence on non-contributory pensions is caused by the expansion of substantial coverage gaps due to the reduction in the number of workers who contribute to the pension schemes. Additionally, the authors in a discussion of the meaning of non-contributory pensions to low-income countries, such as Bolivia, Lesotho, and Bangladesh, find that the share of poor households with a pensioner member is low in lowincome countries with younger populations. Because of this, social pensions in those countries play some role in poverty mitigation, but the impact is limited in scope. In order to generalize, the authors suggest that social pensions in most developing countries may represent core antipoverty programs.

Additionally, research by Barrientos et al. (2003) highlights that non-contributory pensions have significant poverty reduction and prevention effects in those countries: they reduce household poverty and vulnerability and promote functionings ${ }^{11}$ of older people.

Figari, Matsaganis, and Sutherland (2013) find that there is a strong correlation between the resources allocated to minimum pension schemes and reduction in poverty risk

\footnotetext{
${ }^{10}$ Social pensions, which are usually considered non-contributory cash transfers, differ from country to country; they can be universal (also refereed to as basic pensions) or resource tested. Additionally, social pensions may include first-tier public pensions, such as the minimum pension guarantees within mandatory contributory pension schemes in European countries (Holzmann, Robalino, and Takayama 2009).

${ }^{11}$ Barientos et al. define "functionings" as "the beings and doings that people value" (Barrientos et al. 2003).
} 
among the elderly in the European Union. The authors assume that generous minimum pension schemes are more effective in reducing elderly poverty rates than the other pillars of the pension systems.

\section{The Retirement Income Landscape in Georgia}

Currently, the Georgian retirement income landscape includes income from the noncontributory old-age pension, state compensation (pensions for civil service), private, voluntary defined-contribution pension schemes, and other forms of retirement income support, such as formal health care, traditional family support, home and land ownership, etc. However, the old-age pension is the largest system of public support for the elderly and is fundamental in terms of its coverage, spending, and its contribution to elderly consumption. The other components of the Georgian pension system, such as state compensation and voluntary pensions, have low coverage. Additionally, the voluntary pensions in Georgia are not yet developed. Each of these sources of retirement income is discussed further in more detail.

\section{The Basic Pension}

In terms of coverage, spending, and poverty reduction, the basic pension is the pillar of the Georgian pension system and the largest source of public support for the elderly. It provides universal coverage for the elderly and is virtually complete. The largest of several basic pension programs is the old-age pension; it is a pay-as-you-go, universal, flat-rate pension financed by general budget revenues. Currently, the old-age pension is provided to all those reaching retirement age (age 65 for men and 60 for women).

Table 1 provides details on spending and other characteristics of the basic pension in 2009-2013, including the old-age pension, as well as survivor and disability pensions. The table shows that in 2013 the Georgian basic pension was dominated by the old-age pension (86 percent of the all basic pensions). The remainder was accounted for by survivor benefits (about 2 percent of all basic pensions) and disability benefits (about 12 percent).

During 2012-2013, the Georgian government raised the basic pension’s benefit levels, which increased its funding levels to about 4.7 percent of the GDP. As of 2013, the replacement rate of the old age pension reached 17 percent of the average wage (see Table 1).

Old-age pensioners represent 15 percent of the total population of Georgia, which has 
one of the highest percentages an age $65+$ population. ${ }^{12}$ By the end of 2013, the ratio of the population age 65 and older to the age 15-64 population was over 20 percent (see Table 1).

\section{Basic Pension Spending and Government's Fiscal Position}

Since 2012, the Georgian government has increased spending on social provisions, including basic pension, state compensation, social assistance programs, healthcare, etc. ${ }^{13}$ In 2013, the total spending on social provisions accounted for about 29 percent of the state budget total expenditure (see Table 2) and reached about 8 percent of the GDP (see Table 3). The largest component of the social provision spending is the basic pension, which accounted for 60 percent of the total social provisions budget expenditure in 2013 and contributed up to 4.7 percent of the GDP. The primary factor in this increase was the old-age pension, which accounted for over 15 percent of the total state budget expenditures and 4.1 percent of the GDP in 2013 (see Tables 2 and 3).

Given the aging profile of Georgia, spending 4.1 percent of the GDP on old-age pensions is not unreasonable. However, such a large commitment of resources raises the cost of social provision and challenges the sustainability ${ }^{14}$ of the basic pension.

The World Bank (2014) highlights that the effect of the recent increase in social spending will be reflected in a deterioration of the fiscal deficit to 3.7 percent of the GDP in 2014 (see Table 3). The report also underscores that high social spending might increase budget rigidity and restrict fiscal flexibility in the future, which may make Georgia's public finances more vulnerable. Additionally, the report emphasizes the importance of further fiscal consolidation efforts (to create fiscal buffers) and efficient management of public finances for the sustainability of medium- to long-term economic growth and job creation.

However, the Georgian government prioritizes social expenditures and will maintain them at high levels to address the population's need for social assistance and healthcare (Government of Georgia 2014b). Additionally, the Georgian government plans to increase the basic pension up to GEL 160 (from current GEL 150) starting in September 2015 (The Law of Georgia on State Budget 2015).

\footnotetext{
12 In 2014, the share of the population age 65 and older was 15.3 percent in Georgia. This put Georgia among the oldest countries in the world (CIA 2015).

${ }^{13}$ Social provisions in Georgia are significantly financed out of the state budget general revenues.

14 "A sustainable system is one that is financially sound and can be maintained over a foreseeable horizon under a broad set of reasonable assumptions (Holzmann, Hinz, and Dorfman 2008).”
} 


\section{The Pension System's Other Components and Retirement Income Forms}

State Compensation. State compensation was first introduced in 2006. It may be classified as a specific type of non-contributory public pension for civil service. State compensation is provided due to the importance of the work and services that specific workers perform for the state and civil society (The Law of Georgia on State Compensation and State Academic Scholarship 2005). ${ }^{15}$ State compensation aims to secure constitutional social protection for state and civil workers (Social Service Agency 2013). As of 2013, total expenditures on state compensation reached about 0.2 percent of the GDP, covering about 18,012 people, or 3 percent of the population age 65 years and older. State compensation provides a relatively generous retirement income: by the end of 2013 its average benefit reached 58.3 percent of the GDP per capita.

Voluntary Private Pension Schemes. The Georgian voluntary private pension schemes - the third pillar - were implemented in 2007. These pension schemes in Georgia were founded by insurance companies. They are voluntary defined-contribution schemes offered by employers. By law, 80 percent of the defined-contribution schemes' investment reserves should be invested locally in Georgia. At the end of 2013, the number of participants amounted to 18,909 (about 0.9 percent of the labor force). In 2013, the accumulation of these schemes was only 0.048 percent of the GDP. Additionally, the Georgian voluntary pension schemes provide unfettered access to pension savings, which are withdrawn for any purpose by their participants. Also, there are no tax incentives on private pension savings in Georgia (USAID 2011).

Other Forms of Retirement Income Support. The most common source of retirement income support comes in the form of the generous access to informal traditional family support, as Georgians have a very strong sense of family and elderly care obligations. Among other sources of retirement income support are formal health care, ${ }^{16}$ access to individual financial assets (earnings from leasing, dividends, etc.), financial support from

\footnotetext{
${ }^{15}$ State compensation is provided to: staff with rank and senior composition of military service transferred to the reserve of the military organs, internal affairs, special services of state security and Georgian intelligence services; employees dismissed from the investigative service of the Ministry of Finance of Georgia; staff dismissed from the public prosecutor's office; members of the Parliament of Georgia; officials of the Parliament of Georgia; members of the Constitutional Court of Georgia; judges of the Supreme Court of Georgia; judges of the Common Court of Georgia; members of the families of former high political officials of Georgia; people with senior diplomatic rank; the chairperson of the Chamber of Control and his/her deputy (deputies); servants of civil aviation (Social Service Agency 2013).

${ }^{16}$ It is worth noting that during 2012-2013 the Georgian government introduced universal healthcare. Since its introduction, the number of out-patient visits has increased from 9,494.7 in 2012 to 10,974.5 in 2013 (National Statistics Office of Georgia 2014b).
} 
family members (such as remittances and gifts), and non-financial assets such as homeownership and land.

\section{The Basic Pension Outlook}

\section{Population Aging Projections}

The population of Georgia is aging due to increasing longevity and belowreplacement rate fertility ${ }^{17}$ :

- The ratio of population age 60 and older to the population ages 15-59 is projected to increase from 33 percent in 2015 to 60 percent by 2075 (see Figure 6).

- Fertility rates are projected to remain quite low over the coming decades. Fertility rates in Georgia from 2010-2015 stood at around 1.81 children per woman. Fertility rates are projected to slightly increase up to 1.87 by $2070-2075$.

- Life expectancy is currently 70.5 years for men and 77.7 years for women (20102015). Life expectancy for men at age 60 is projected to increase from the current 17.50 to 22.93 by 2075 , and for women at age 60, from the current 21.62 to 26.73 by 2075.

\section{Basic Pension Spending Projections}

The most practical and politically appropriate assumption is that spending on the noncontributory basic pensions will increase in line with wage growth. Historically, the basic pension has experienced several ad hoc increases based upon political decisions. For instance, in 2012 and 2013, the basic pension increased faster than wages (World Bank 2014). It is more predictable - and more politically feasible - that the government will keep basic pensions from falling or may even increase them. Taking this into consideration, wage indexation would be assumed to be the most appropriate policy response. Currently there are no pension indexation rules in Georgia. Figure 7 shows the baseline projection for the basic pension, if wage indexation were implemented.

Figure 8 shows the basic pension projection under current law and therefore does not assume indexation policy.

The baseline projection shows that indexing the basic pension to wage increases not only helps to maintain its adequacy but also would be important to the continued alleviation of poverty in Georgia. However, this baseline projection also shows that the long-term cost

\footnotetext{
${ }^{17}$ This paper is based on the United Nations data and projections.
} 
of the basic pension system increases from 4.7 percent of the GDP in 2015 to 7.4 percent of the GDP by 2075 (see Figure 7). This increase, which is in line with an increase in old age dependency ratio, shows that the basic pension system over the long term will become unsustainable.

To maintain the system's sustainability without introducing any other reforms, it will be necessary to raise taxes to finance the basic pension out of the general tax revenues or to cut benefits. None of these options is appropriate. Fiscal resources in Georgia are scarce taxes are already high, and there is a constitutional provision that bars the government from increasing taxes (World Bank 2014). On the other hand, reductions in benefit levels would undermine the poverty alleviation feature of the basic pension. An additional option is to cut the state budget expenditures on some other governmental programs, though this is not feasible politically.

\section{Options for Reform}

Two factors limit the future sustainability of Georgia's non-contributory basic pension. The country is characterized by an aging population and scarce public financial resources, which create many pressing needs for social provision, including the basic pension, social assistance, health care, etc. Consequently, the key goals of the basic pension reform are how to ensure:

- Maintaining reasonable funding burdens while also maintaining the long-term sustainability and adequacy of the pension system; and

- Sufficient flexibility in the system to adapt to the evolving demographic environment.

\section{Four Pension Reform Options Are Considered Further}

Scenario 1: Indexing Future Pension Benefits to Prices. Among the different parametric reform options, indexation to prices would be considered to protect the purchasing power of pensions. It is worth mentioning that the Georgian government intends to link the basic pension to inflation until 2020 (Government of Georgia 2014b).

Figure 9 shows the impact of price indexation reform on the basic pension: it would result in low pension spending (1.9 percent of the GDP in 2075) but also in lower, inadequate pension benefits (average benefit drops from 12.5 percent of the GDP per worker to 3.2 percent by the end of the projected period). The lower benefits will undermine the ability of the basic pension to alleviate relative poverty. 
Scenario 2: Increasing Retirement Ages. Generally, a parametric pension reform, which aims to reduce the cost of the pension system, may include curtailing eligibility (i.e., changing the number of eligible pensioners by increasing the statutory retirement ages). Curtailing eligibility in Georgia should be considered, as life expectancy at age 60 is projected to increase in coming decades.

This option potentially can help to contain pension spending, avoid a socially and politically undesirable decrease in the pension replacement rate, encourage longer stays in the labor market, contribute to economic growth, and improve the fiscal sustainability of a pension system (Eich, Gust, and Soto, 2012).

Table 4 proposes reasonable increases in Georgia's retirement ages, starting in 2025, and a schedule for equalizing retirement ages between men and women, who live longer than men. The retirement ages can be increased and equalized gradually: to age 65 for women after 2020, and then to age 68 for both men and women by 2060 .

Figure 10 shows the impact on government pension expenditures and on pension benefit levels of changing and equalizing retirement ages: basic pension spending increases from 4.7 percent of the GDP in 2015 to 5 percent in 2075.

This policy reform option also has the potential to stabilize the ratio of pensioners to the working-age population (see Figure 11). Additionally, this policy reform option may induce longer stays in the labor market, which could contribute to consumer spending and economic growth.

However, it should be noted that in Georgia increasing and equalizing statutory retirement ages may be quite controversial if we take into account the environment there: high levels of unemployment and a large informal sector. For instance, over 60 percent of working-age Georgians were self-employed in 2013. Self-employment is most common among rural populations (National Statistics Office of Georgia 2014a). Increasing and equalizing statutory retirement ages will be easier if agriculture develops in Georgia. However, if this policy option is implemented, the problem of low employment in urban areas may cause an increase in urban poverty levels.

Increasing and equalizing retirement ages may also impact Georgian women unfavorably, as traditionally women in Georgia tend to stay home, i.e., employment among women is low (National Statistics Office of Georgia 2014a).

Scenario 3: Reducing Pension Generosity Through Means Testing. Reducing the generosity of benefits is one of the reform options, which would reduce the fiscal burden of the pension system. It may be done by the adoption of means testing. Such a parametric 
change in the Georgian basic pension system can be done simultaneously with an introduction of compulsory pension insurance, including implementation of second-pillar mandatory contributory pension schemes, which have been suggested by the Georgian government since 2012 and reflected in government documents and laws (Government of Georgia 2012; 2013, 2014; 2015; The Law of Georgia on State Budget 2013; 2014; 2015). ${ }^{18}$

Assuming that contributory pension schemes function successfully, they will enable high-earning participants who contribute to save enough so that they would no longer need a basic pension, which would exist primarily for poverty relief - and not to finance old age for people with higher earnings. This policy reform option would reduce participation in the basic pension system by 15 percent (by means of restricted eligibility criteria) starting in 2045 when pension payments will be available for the participants in the contributory pension schemes (see Figure 12).

However, Figure 13 shows that this proposal alone would not be enough to maintain the basic pension system's sustainability. Despite the fact that the cost of funding the system - if a second-pillar contributory scheme is added - is lower than in the baseline projection, pension spending still increases from 4.7 percent of the GDP in 2015 to 6.3 percent of the GDP by 2075 (Figure 13).

Reducing the generosity of benefits under the basic pension by means testing is also controversial. A second pillar pension scheme that is mandatory and earnings-related would create uncertainty in Georgia: this systemic reform option may not be implemented, or, if implemented it may be reversed or changed. Additionally, there is a level of uncertainty regarding the successful functioning of a contributory pension scheme in Georgia, since there is a lack of capital market capacity and a regulatory framework to manage earnings-related pension schemes. Moreover, the introduction of such a systemic reform may widen the state budget deficit and decrease basic pension spending, which will, in turn, affect the sustainability and adequacy of the basic pension program. ${ }^{19}$

\footnotetext{
${ }^{18}$ Implementation details for the second-pillar contributory pension schemes are not clearly described in government documents. However, it is assumed that defined contribution pension schemes, partially funded by employers, employees, and the state budget, will be implemented in Georgia to complement the basic pension (Pension Reform Unit of the Ministry of Economy and Sustainable Development of Georgia).

${ }^{19}$ There is evidence that in emerging economies in Latin America and Europe, specific risks arise from the transition to multi-pillar pension systems. In these countries, pension reforms that led to the introduction of mandatory private pensions improved the long-term sustainability of public finances. However, the large transition costs arising from diverting contributions to mandatory private pensions have widened budget deficits and increased borrowing requirements in the near-term. Additionally, there is also the risk that replacement rates in private defined contribution schemes could be inadequate to ensure old-age income in retirement, especially for low-income groups, and, therefore, create pressures for higher social pension spending (International Monetary Fund 2011).
} 
Another reason that this policy reform option would be considered controversial is because means testing may introduce distortions related to disincentives on retirement savings (Biggs 2011).

Scenario 4: Simultaneous Reforms: Increasing Retirement Ages and Reducing the Generosity of Benefits by Means Testing. Some of the previously discussed options for improving and developing the basic pension system in Georgia can be combined into a more appropriate policy reform choice. The medium- and long-term sustainability of the basic pension system can be achieved by undertaking a combination of means testing and a gradual increase and equalization of the retirement ages. This reform mix assumes increasing the statutory retirement ages for women to age 65 after 2020, and for both men and women to age 68 by 2060; and introducing means testing in 2045, as the proposed contributory pension schemes become fully functional.

Figure 14 shows that a reform mix will help to ensure a sustainable fiscal position: the cost of the basic pension will be stabilized to around 5 percent of the GDP throughout the projected period. This policy reform option will also help to maintain pension benefits on a consistent level (i.e., the average benefit as percent of the GDP per worker is stabilized at 12 percent).

In addition to its fiscal impact, this policy reform mix would have the potential to increase labor force participation and, therefore, to contribute to the economic growth in Georgia.

\section{Conclusion}

One of the main objectives of Georgian social policy is to reduce poverty and the social risks caused by the aging of the country's population (Government of Georgia 2015). A reform of the non-contributory basic pension system might play a substantial role in achieving this objective. Therefore, the main goal of the pension reform in Georgia should be to maintain the sustainability of the basic pension system and its poverty alleviation feature. The appropriate reform mix might include an increase in retirement ages and a reduction in the generosity of benefits through means testing.

This paper finds that increasing the statutory retirement ages for women to age 65 after 2020, and then increasing the retirement ages for both men and women to age 68 by 2060 is an attractive policy option that helps to ensure that basic pension benefits are adequate and helps to contain government spending on basic pensions and potentially improve fiscal sustainability. This policy reform option has the further benefit of potentially 
stabilizing the ratio of pensioners to the working-age population, increasing labor-force participation and, therefore, to contribute to the economic growth in Georgia.

Additionally, an increase in the retirement ages should be supplemented with other social assistance measures that protect the incomes of those who cannot continue to work, so as to prevent increases in Georgia's poverty rate. This may also lead to potential reforms to disability pensions. Moreover, it should be politically feasible to limit early retirement and, also, to facilitate women's labor force participation in Georgia.

Means-tested benefits have the advantage of being less costly than Georgia's current system of universal benefits. The most important implication associated with means testing which should be addressed by policymakers - is the inherent potential to provoke disincentives to work and save. This may adversely affect development of the proposed second pillar contributory pension schemes. The main challenge related to this policy option would be to create a policy that avoids the negative consequences of means testing, while making means testing an efficient solution for improving the sustainability of the basic pension system in Georgia.

Eventually, means testing would change the nature of the basic pension through its transformation: it will transform the universal basic pension into a pension for the poor. Economic growth and institutional improvement in Georgia may facilitate gradual development of the proposed second pillar pension system and even a voluntary third pillar system. The generosity of the basic pension system might be reduced, contingent on the development of the contributory pension schemes.

Finally, in the medium-term perspective, the basic pension program must be complemented by an implementation of improved and effective social assistance and health programs targeting the elderly as well as other vulnerable populations who are in extreme poverty. This might enhance the effectiveness of the basic pension in mitigating poverty in Georgia. 


\section{References}

Barrientos, Armando et al. 2003. "Non-Contributory Pensions and Poverty Prevention: A Comparative Study of Brazil and South Africa.” Final Report, DFID Project R7897, Pensions and Poverty Prevention. Manchester, London, UK.

Available at: http://www.globalaging.org/pension/world/2004/noncontributory.pdf.

Baumann, Eveline. 2012. "Post-Soviet Georgia: It’s a Long, Long Way to “Modern” Social Protection.” Economies et Sociétés. Série Développement, Croissance et Progrès 46(2): 259-285.

Biggs, Andrew G. 2011. “Means Testing and Its Limits.” National Affairs 9: 97-112. Available at: http://www.nationalaffairs.com/doclib/20110919_Biggs.pdf.

Buckley, Cynthia. 1998. "Obligations and Expectations: Renegotiating Pensions in the Russian Federation.” Continuity and Change 13(2): 317-338.

Central Intelligence Agency. 2015. “The World Factbook. Age Structure.” Available at: https://www.cia.gov/library/publications/the-worldfactbook/fields/2010.html\#4.

Clements, Benedict, Frank Eich, and Sanjeev Gupta. 2014. Equitable and Sustainable Pensions: Challenges and Experience. Washington, DC: International Monetary Fund.

de Castello Branco, Marta. 1996. “Georgia from Hyperinflation to Growth.” IMF Survey. Washington, DC: International Monetary Fund.

Available at: https://www.imf.org/external/pubs/ft/survey/pdf/092396b.pdf.

de Castello Branco, Marta. 1998. "Pension Reform in the Baltics, Russia and Other Countries of the Former Soviet Union (BRO).” IMF Working Paper 98/11. Washington, DC: International Monetary Fund.

Available at: http://www.imf.org/external/pubs/ft/wp/wp9811.pdf.

Economic Policy Research Center. 2013. “Do We Need a Pension Reform?” Tbilisi, Georgia. Available at: http://www.csogeorgia.org/uploads/library/113/sapensio_repormaeng.pdf.

Eich, Frank, Charleen Gust, and Mauricio Soto. 2012. "Reforming the Public Pension System in the Russian Federation.” IMF Working Paper 12/201. Washington, DC:

International Monetary Fund.

Available at: https://www.imf.org/external/pubs/ft/wp/2012/wp12201.pdf.

European Initiative - Liberal Academy Tbilisi. 2012. "The Economic Transformation of Georgia: 20 Years of Independence.” Interim Report. Tbilisi, Georgia. Available at: http://www.ei-lat.ge/images/stories/The_Economic_Transformation_of_Georgia__20_Years_of_Independence_Interim_Report_geo.pdf. 
Figari, Francesco, Manos Matsaganis, Holly Sutherland. 2013. “The Financial Well-Being of Older People in Europe and the Redistributive Effects of Minimum Pension Schemes.” Rivista Italiana Degli Economisti 18(2): 149-173.

Government of Georgia. 2012; 2013; 2014a; 2015. “Government Program: For Strong, Democratic and Unified Georgia.” Tbilisi, Georgia.

Available at: http://gov.ge/index.php?lang_id=GEO\&sec_id=68.

Government of Georgia. 2014b. “Social-Economic Development Strategy of Georgia “Georgia 2020”. Tbilisi, Georgia.

Available at: http://www.adb.org/sites/default/files/linked-documents/cps-geo-20142018-sd-01.pdf.

Gugushvili, Alexi. 2009. "Political Economy of Old-Age Pension Reforms in Georgia.” Caucasian Review of International Affairs 3(4): 371-386.

Holzmann, Robert and Richard Hinz. 2005. Old Age Income Support in the 21st Century. Washington, DC: The World Bank.

Holzmann, Robert, David A. Robalino, and Noriyuki Takayama. 2009. Closing the Coverage Gap: The Role of Social Pensions and Other Retirement Income Transfers. Washington, DC: The World Bank.

Holzmann, Robert, Richard Paul Hinz, and Mark Dorfman. 2008. "Pension Systems and Reform Conceptual Framework.” Discussion Paper No. 0824. Washington, DC: World Bank. Available at: http://siteresources.worldbank.org/SOCIALPROTECTION/Resources/SPDiscussion-papers/Pensions-DP/0824.pdf.

International Monetary Fund. 2011. "The Challenge of Public Pension Reform in Advanced and Emerging Economies.” IMF Policy Paper. Washington, DC: International Monetary Fund.

Available at: http://www.imf.org/external/np/pp/eng/2011/122811.pdf.

Jian-Ye Wang. 1999. “The Georgian Hyperinflation and Stabilization.” IMF Working Paper 99/65. Washington, DC: International Monetary Fund.

Available at: http://www.imf.org/external/pubs/ft/wp/1999/wp9965.pdf.

Ministry of Finance of Georgia. "Country Basic Data and Directions (2012-2015; 2013-2016; 2014-2017; 2015-2018).” Tbilisi, Georgia. Available at: http://www.mof.ge/en/4543.

National Bank of Georgia. 2001. "Bulletin of Monetary and Banking Statistics.” 12(34). Available at:

https://www.nbg.gov.ge/uploads/publications/bulletinstatistics/statbiul/2013/annualge o/bulletin2001geo.pdf.

National Statistics Office of Georgia. 2014a. "Employment and Unemployment 2013.” Annual Report. Tbilisi, Georgia. Available at: http://www.geostat.ge/cms/site_images/_files/georgian/labour/dasaqmeba\%20da\%20 umuSevroba\%202014\%20pres-relizi.pdf. 
National Statistics Office of Georgia. 2014b. “Statistical Yearbook of Georgia 2013.” Tbilisi, Georgia. Available at:

http://www.geostat.ge/cms/site_images/_files/yearbook/Yearbook_2014.pdf.

Palacios, Robert and Charles Knox-Vydmanov. 2014. "The Growing Role of Social Pensions: History, Taxonomy and Key Performance Indicators.” Public Administration and Development 34(4): 251-264.

Pension Reform Unit of the Ministry of Economy and Sustainable Development of Georgia. "Personal Communication with Pension Reform Unit Head Otar Dzidzikashvili." Tbilisi, Georgia.

Schwarz, Anita, Omar S. Arias, et al. 2014. “The Inverting Pyramid: Pension Systems Facing Demographic Challenges in Europe and Central Asia.” Europe and Central Asia Reports. Washington, DC: The World Bank. Available at: http://www.worldbank.org/content/dam/Worldbank/Feature\%20Story/ECA/ECAPensions-Report-2014.pdf.

Social Service Agency. 2014. “Social Statistics 2013.” Annual Report. Tbilisi, Georgia. Available at: http://ssa.gov.ge/files/01_GEO/PUBLIKACIEBI/FILES/STAT2013.pdf.

Social Service Agency. 2013. "State Compensation. Whom the State Compensation Maybe Assigned to.” Available at: http://ssa.gov.ge/index.php?sec_id=24\&lang_id=ENG.

Statistical Office of the European Commission (Eurostat). 2014. “Glossary: At-Risk-ofPoverty Rate.” Available at: http://ec.europa.eu/eurostat/statisticsexplained/index.php/Glossary:At-risk-of-poverty_rate.

The Law of Georgia on State Budget (2013; 2014; 2015).

The Law of Georgia on State Compensation and State Academic Scholarship (2005).

The Law of Georgia on State Pension (2005).

United Nations International Children’s Emergency Fund (UNICEF). 2012. “Georgia: Reducing Child Poverty.” A Discussion Paper. Georgia, Tbilisi: UNICEF (Georgia). Available at: http://www.unicef.org/ceecis/UNICEF_Child_PovertyENG_web_with_names.pdf.

United Nations Population Division. "Personal Communication with Estimates and Projections Section Population Officer Kirill Andreev.” New York, NY.

United States Agency for International Development (USAID). 2011. "Pension Development in Georgia.” Final Report. Tbilisi, Georgia. Available at: http://pdf.usaid.gov/pdf_docs/pnadz449.pdf.

World Bank. 2015a. “Data. GNI Per Capita, PPP.” Available at: http://data.worldbank.org/indicator/NY.GNP.PCAP.PP.CD. 
World Bank. 2015b. "Europe and Central Asia Overview.” Available at:

http://www.worldbank.org/en/region/eca/overview\#1.

World Bank. 2014. "Georgia: Public Expenditures Review. Strategic Issues and Reform Agenda.” Report No. 78143-GE 2014. Washington, DC. Available at: http://wwwwds.worldbank.org/external/default/WDSContentServer/WDSP/IB/2014/07/31/00033 3037_20140731104244/Rendered/PDF/781430GE0v10RE0Box0385291B00PUBLIC $\underline{0 . p d f}$. 
Table 1. Basic Pension Spending and Demographics, 2009-2013

\begin{tabular}{|c|c|c|c|c|c|}
\hline & 2009 & 2010 & 2011 & 2012 & 2013 \\
\hline \multicolumn{6}{|c|}{ Pension spending (percent of GDP) } \\
\hline Basic pension & 4.1 & 3.8 & 3.5 & 4.1 & 4.7 \\
\hline Old-age pension & 3.4 & 3.1 & 2.9 & 3.5 & 4.1 \\
\hline Survivor pensions/benefits & 0.1 & 0.1 & 0.1 & 0.1 & 0.1 \\
\hline Disability pensions/benefits & 0.6 & 0.6 & 0.5 & 0.5 & 0.5 \\
\hline \multicolumn{6}{|c|}{ Replacement rate (in percent of average wage) } \\
\hline Average old-age pension & 13.9 & 13.6 & 13.7 & 15.0 & 17.1 \\
\hline \multicolumn{6}{|l|}{ Demographics } \\
\hline Old-age pensioners & 659,964 & 662,288 & 666,367 & 682,886 & 686,675 \\
\hline Receivers of survivor benefits & 35,499 & 32,120 & 28,469 & 28,193 & 27,080 \\
\hline Receivers of disability benefits & 139,932 & 138,614 & 129,599 & 122,056 & 122,940 \\
\hline $\begin{array}{l}\text { Share of old-age pensioners in } \\
\text { total number of the } \\
\text { recipients of the basic } \\
\text { pension, percent }\end{array}$ & 78.7 & 79.2 & 80.6 & 82.0 & 82.1 \\
\hline $\begin{array}{l}\text { Share of old-age pensioners in } \\
\text { total population, percent }\end{array}$ & 15.1 & 15.0 & 15.0 & 15.2 & 15.3 \\
\hline $\begin{array}{l}\text { Old-age dependency ratio } \\
(65+/ 15-64), \text { percent }\end{array}$ & 21.0 & 20.3 & 20.0 & 19.7 & 20.0 \\
\hline
\end{tabular}

Sources: Social Service Agency of Georgia, Pension Reform Unit of the Ministry of Economy and Sustainable Development of Georgia, National Statistics Office of Georgia, and authors’ calculations.

Table 2. State Budget (Selected Expenditure Lines), 2009-2014

\begin{tabular}{|c|c|c|c|c|c|c|}
\hline Year & 2009 & 2010 & 2011 & 2012 & 2013 & 2014 \\
\hline $\begin{array}{l}\text { State Budget total expenditure, } \\
\text { million GEL }\end{array}$ & 6113,9 & 6340,0 & 6682,6 & 7 179,2 & 7235,8 & 7 392,6* \\
\hline $\begin{array}{l}\text { Social provision, million GEL } \\
\text { Share of social provision in State }\end{array}$ & 1419,9 & 1481,1 & 1540,9 & 1710,3 & 2 083,0 & 2 489,7* \\
\hline $\begin{array}{l}\text { Budget total expenditure, } \\
\text { percent }\end{array}$ & 23.2 & 23.4 & 23.1 & 23.8 & 28.8 & $33.7^{*}$ \\
\hline $\begin{array}{l}\text { Basic pension, million GEL } \\
\text { Share of basic pension in State }\end{array}$ & 810,5 & 850,5 & 899,7 & 1012,3 & 1251,2 & 1451,8 \\
\hline $\begin{array}{l}\text { Budget total expenditure, } \\
\text { percent }\end{array}$ & 13.3 & 13.4 & 13.5 & 14.1 & 17.3 & $19.6 *$ \\
\hline $\begin{array}{l}\text { Old-age pension, million GEL } \\
\text { Share of old-age pension in State }\end{array}$ & 604,6 & 640,9 & 697,2 & 915,3 & 1094,7 & 1257,1 \\
\hline $\begin{array}{l}\text { Budget total expenditure, } \\
\text { percent }\end{array}$ & 9.9 & 10.1 & 10.4 & 12.7 & 15.1 & $17.0 *$ \\
\hline
\end{tabular}

Note: Data is reported in current prices. Additionally, the average exchange rate of the U.S. dollar to GEL during 2014 was 1.77 ; * 2014 projection.

Sources: Ministry of Finance of Georgia, National Statistics Office of Georgia, Social Service Agency of Georgia, Pension Reform Unit of the Ministry of Economy and Sustainable Development of Georgia, and authors' calculations. 
Table 3. State Budget (Selected Expenditure Lines) and Overall Fiscal Deficit, in Percent of GDP, 2009-2014

\begin{tabular}{lcccccc}
\hline Year & 2009 & 2010 & 2011 & 2012 & 2013 & 2014 \\
\hline State Budget total expenditure & 34 & 30.6 & 27.5 & 27.4 & 27 & $25^{*}$ \\
Social provision & 7.9 & 7.1 & 6.3 & 6.5 & 7.8 & $8.5^{*}$ \\
Basic pension & 4.5 & 4.1 & 3.7 & 3.9 & 4.7 & $5.0^{*}$ \\
Old-age pension & 3.4 & 3.1 & 2.9 & 3.5 & 4.1 & $4.3^{*}$ \\
Overall fiscal deficit & -9.2 & -6.5 & -3.5 & -2.8 & -2.5 & $-3.7^{* *}$ \\
\hline
\end{tabular}

Notes: * Projection for 2014 (Authors’ calculations); ** Projection for 2014 (The World Bank report).

Sources: International Monetary Fund; Ministry of Finance of Georgia; National Statistics Office of Georgia; Social Service Agency of Georgia; Report "Georgia: Public Expenditure Review. Strategic Issues and Reform Agenda”, p. 19., 2014. The World Bank; and authors’ calculations.

Table 4. Statutory Retirement Ages: Proposed Increases, 2015-2060

\begin{tabular}{lcc}
\hline Year & Retirement age: Men & Retirement age: Women \\
\hline 2015 & 65 & 60 \\
2025 & 65 & 62 \\
2030 & 65 & 65 \\
2040 & 66 & 66 \\
2050 & 67 & 67 \\
2060 & 68 & 68 \\
\hline
\end{tabular}

Source: Authors’ proposal. 
Figure 1. Old-Age Average Pension as a Percent of GDP Per Capita, 2006-2013

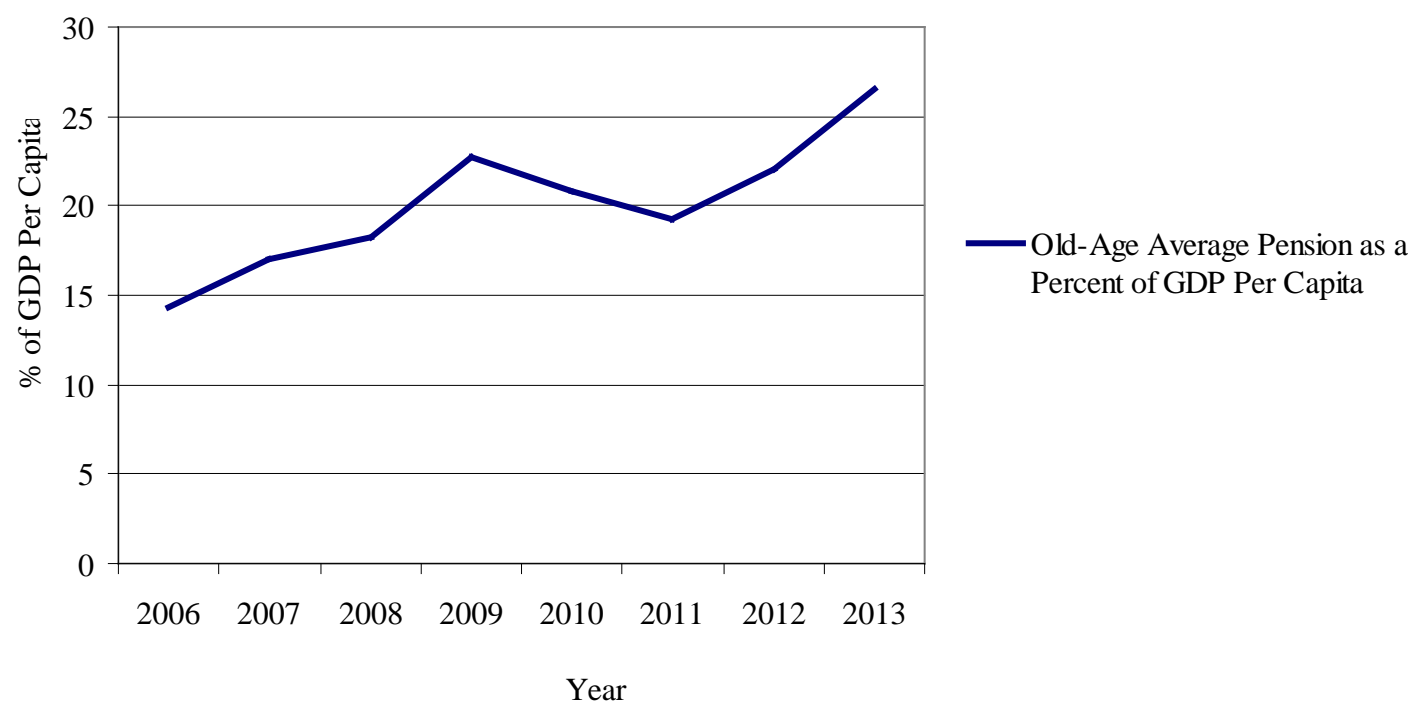

Sources: World Bank, National Bank of Georgia, Pension Reform Unit of the Ministry of Economy and Sustainable Development of Georgia, National Statistics Office of Georgia, and authors' calculations.

Figure 2. Correlation Between the Increase in Old-Age Average Pension and the Reduction in Relative Elderly Poverty, 2004-2013

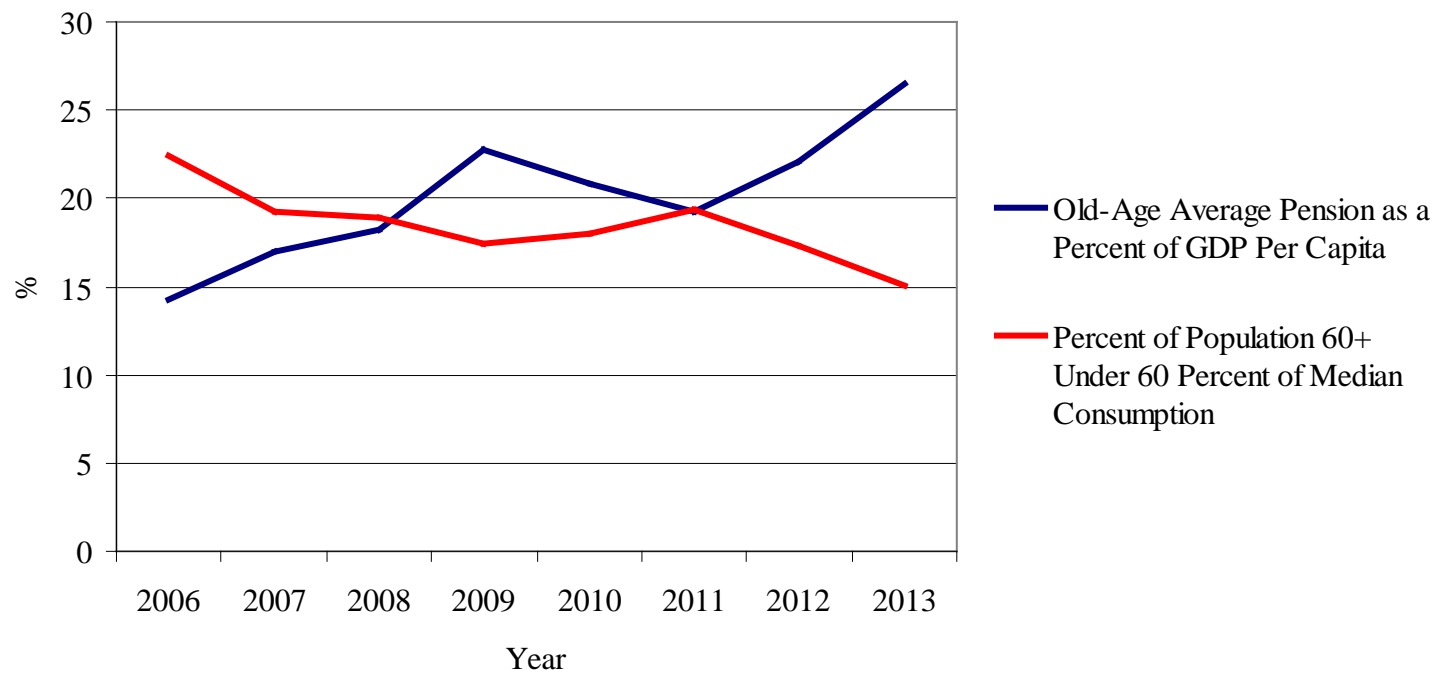

Sources: World Bank, National Bank of Georgia, Pension Reform Unit of the Ministry of Economy and Sustainable Development of Georgia, National Statistics Office of Georgia, and authors’ calculations. 
Figure 3. Relative Poverty: Share of Population (Children, Working age, Elderly) Under 60 Percent of Median Consumption, 2004 - 2013

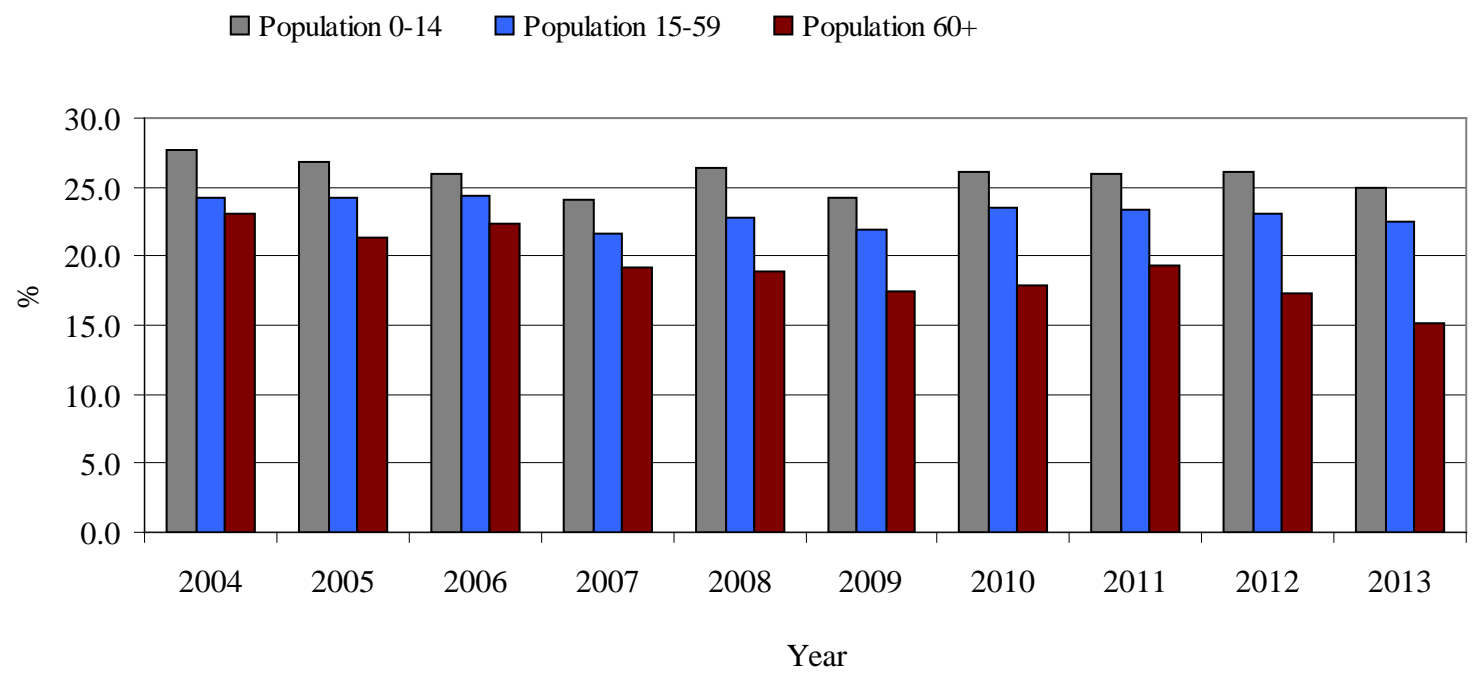

Source: National Statistics Office of Georgia.

Figure 4. Estimated Effect of Pension Income on Consumption Poverty: Percent of Households, Children and Pensioners Living in Poverty Before and After Deduction of Pension Income, 2011

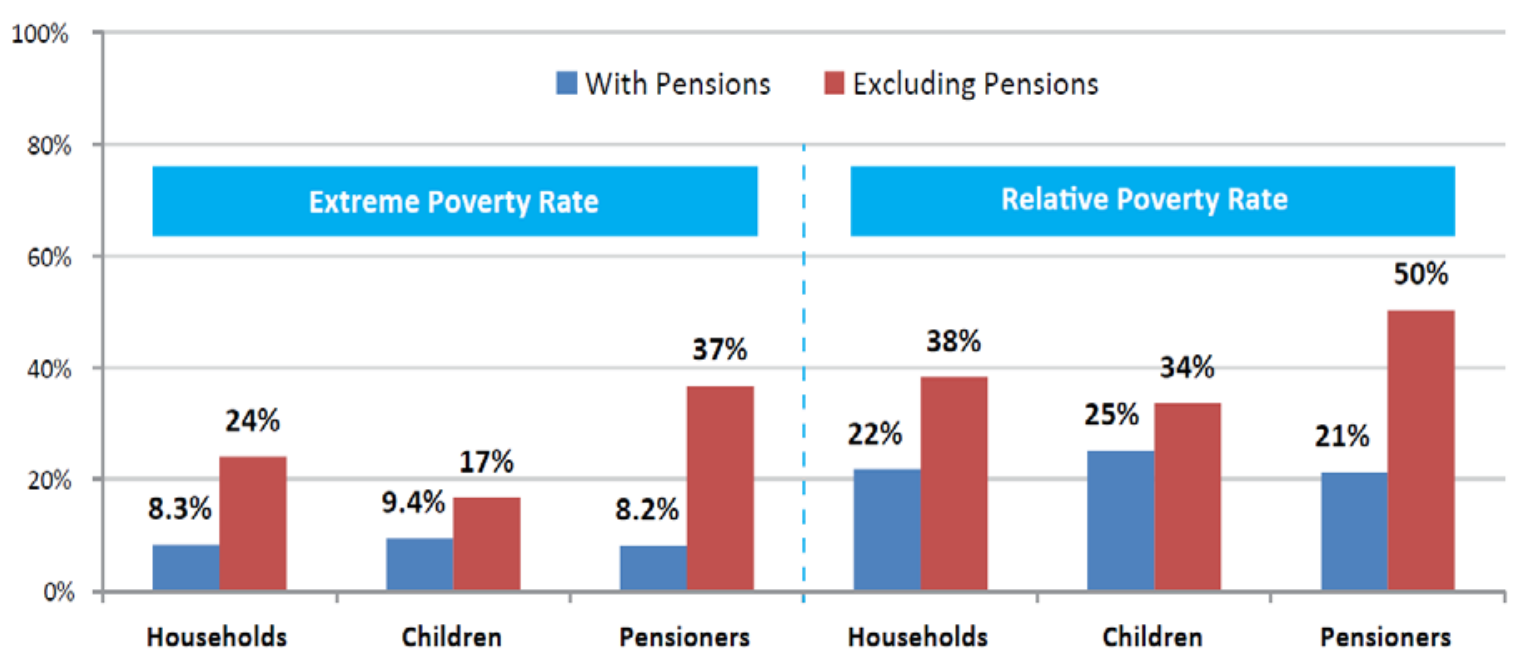

Source: UNICEF (2012). 
Figure 5. Percentage of Households With and Without a Pensioner in Poverty, in Selected European and Central Asian Economies, 2009

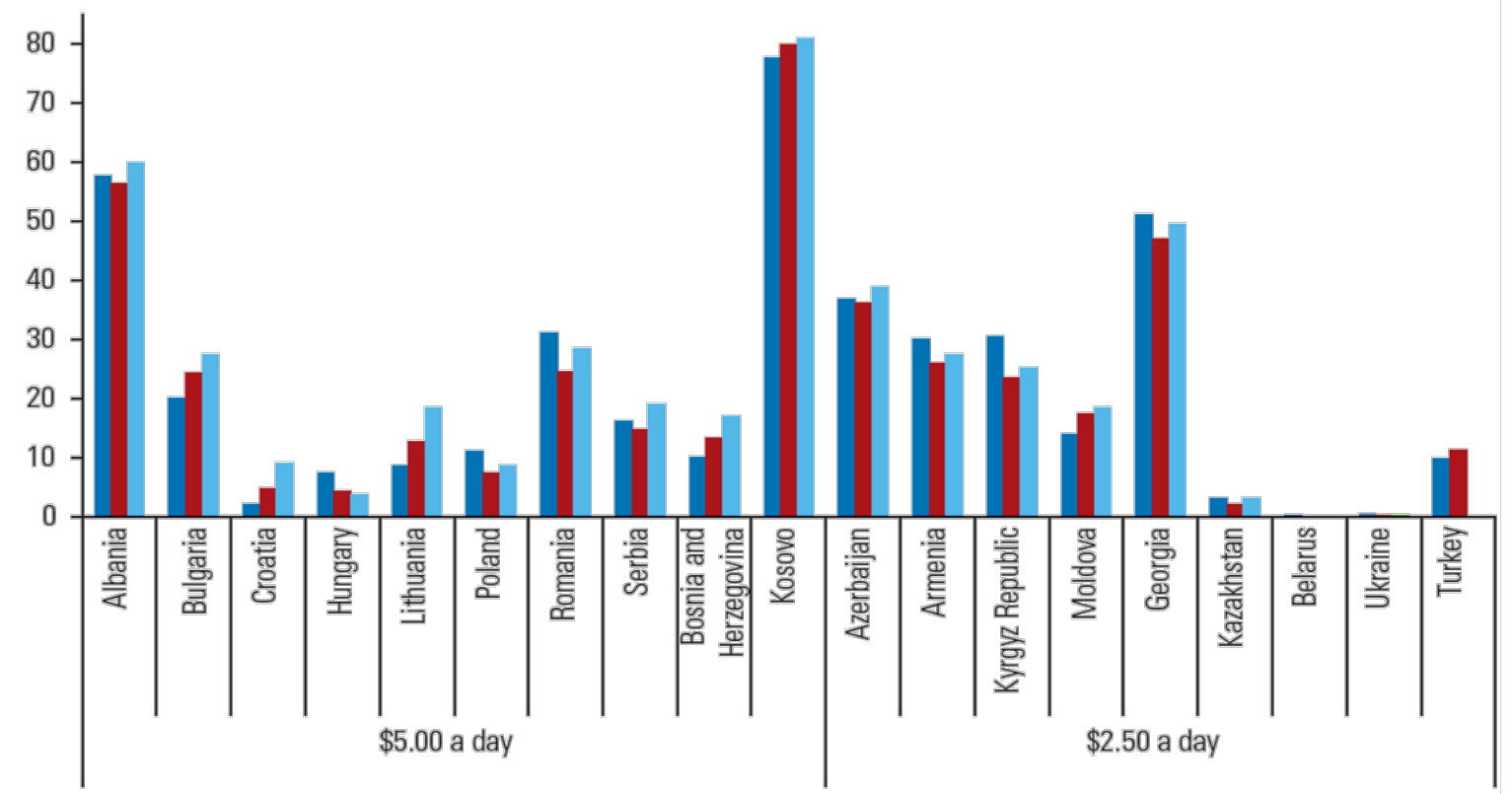

Households with no pensioners $\quad$ Households with pensioners 65+ $\quad$ Households with pensioners $80+$

Source: Anita M. Schwarz and Omar S. Arias (2010).

Figure 6. Ratio of Population Older Than 60 to Population 15-59, 2015 - 2075

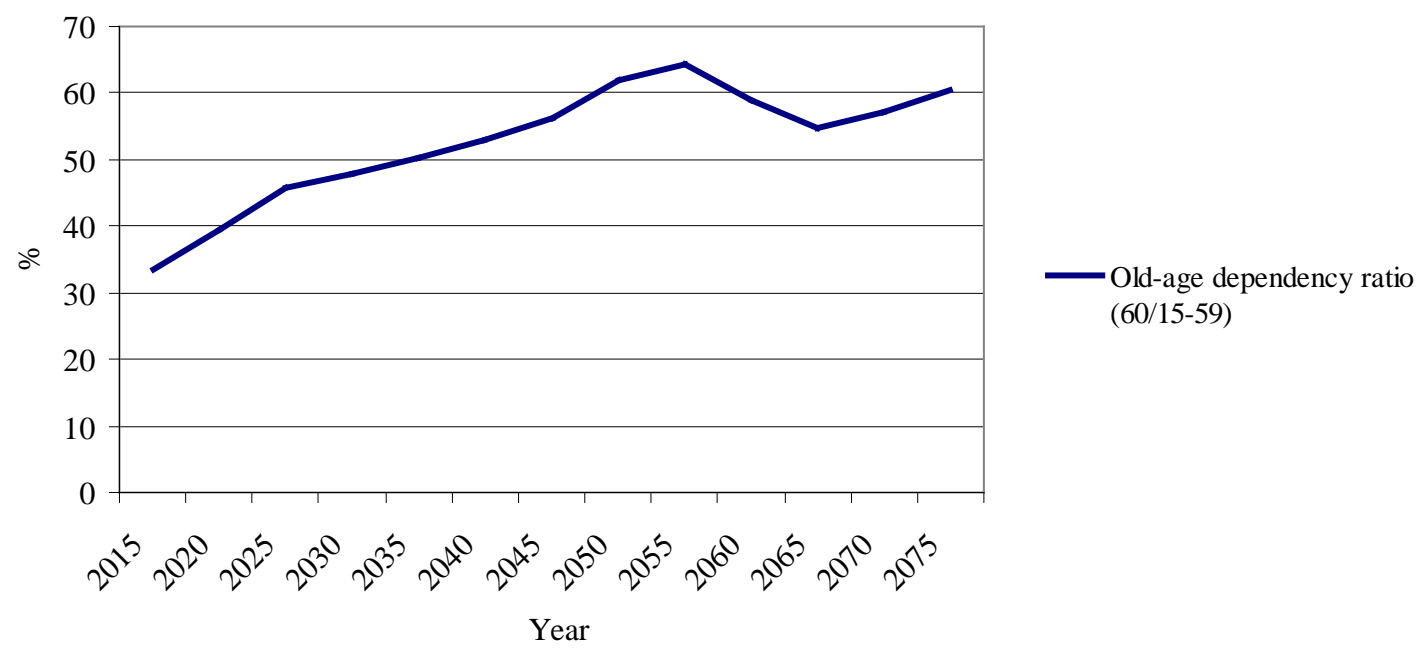

Note: The old-age dependency ratio drops from 64 percent to 55 percent in 2055-2065, due to rapid declines in fertility rates in the early 2000s and associated small population cohorts (United Nations Population Division). Source: United Nations. 
Figure 7. Baseline Projection: Average Benefit as Percent of GDP Per Worker, Basic Pension Spending, Percent of GDP, 2015-2075

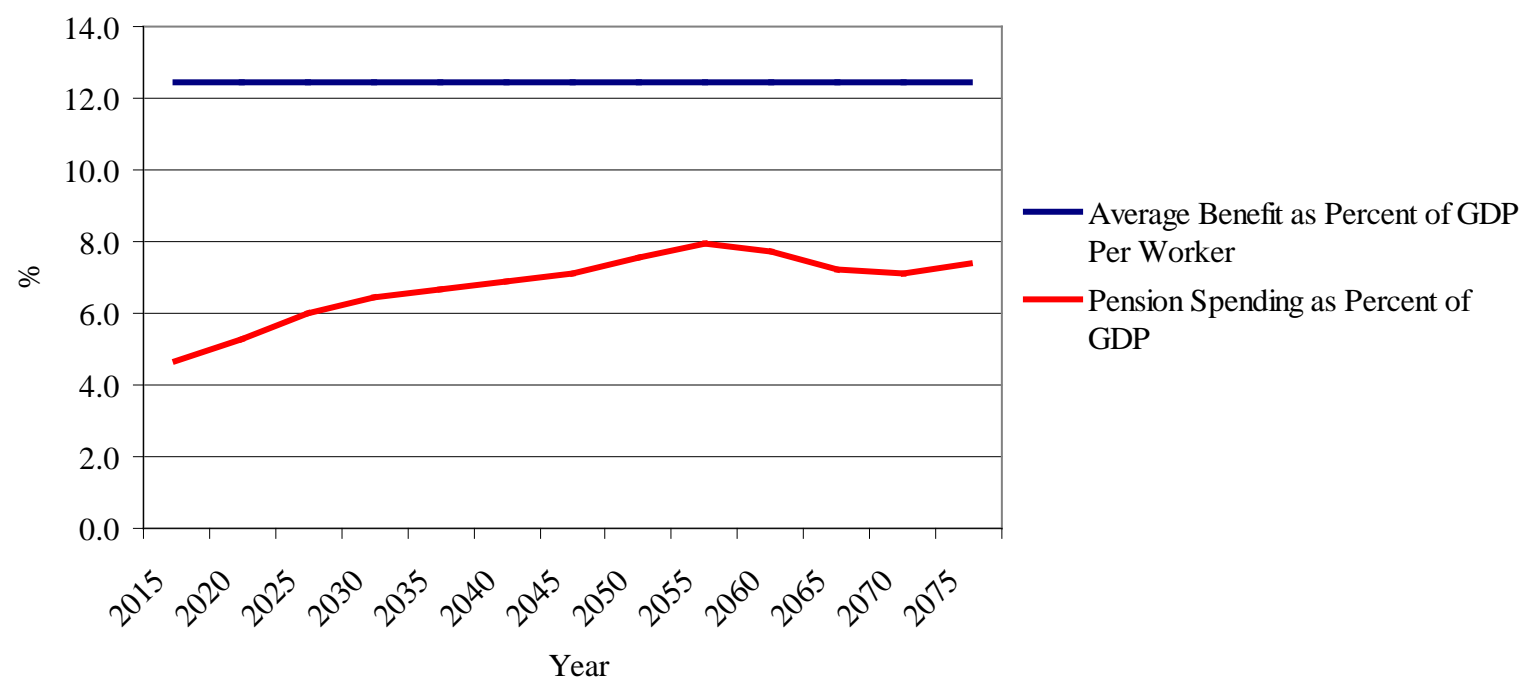

Source: Authors' calculations.

Figure 8. Projection, Based on the Current Legal Conditions: Average Benefit as Percent of GDP Per Worker, Basic Pension Spending, Percent of GDP, 2015-2075

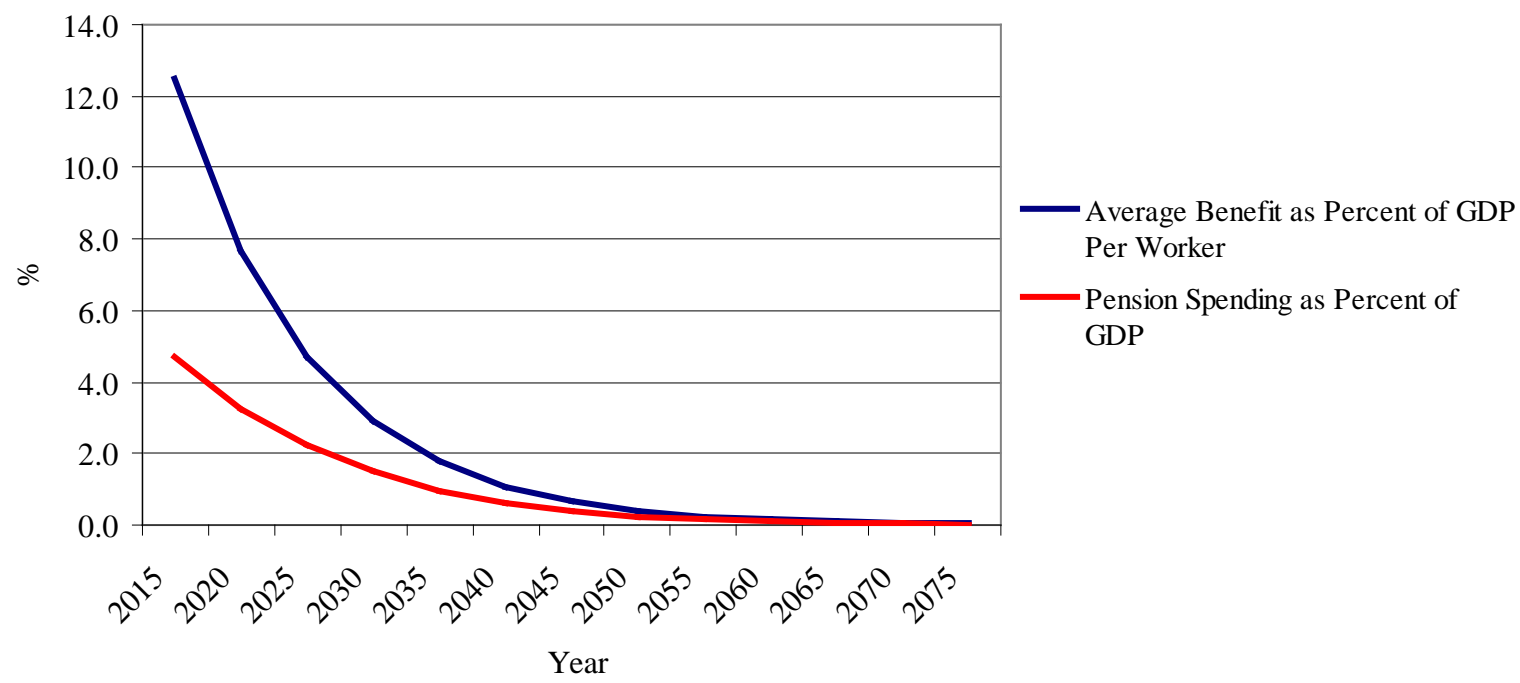

Source: Authors' calculations. 
Figure 9. Changes in Price Indexation, Relative to Baseline: Average Benefit as Percent of GDP Per Worker, Basic Pension Spending, Percent of GDP, 2015-2075

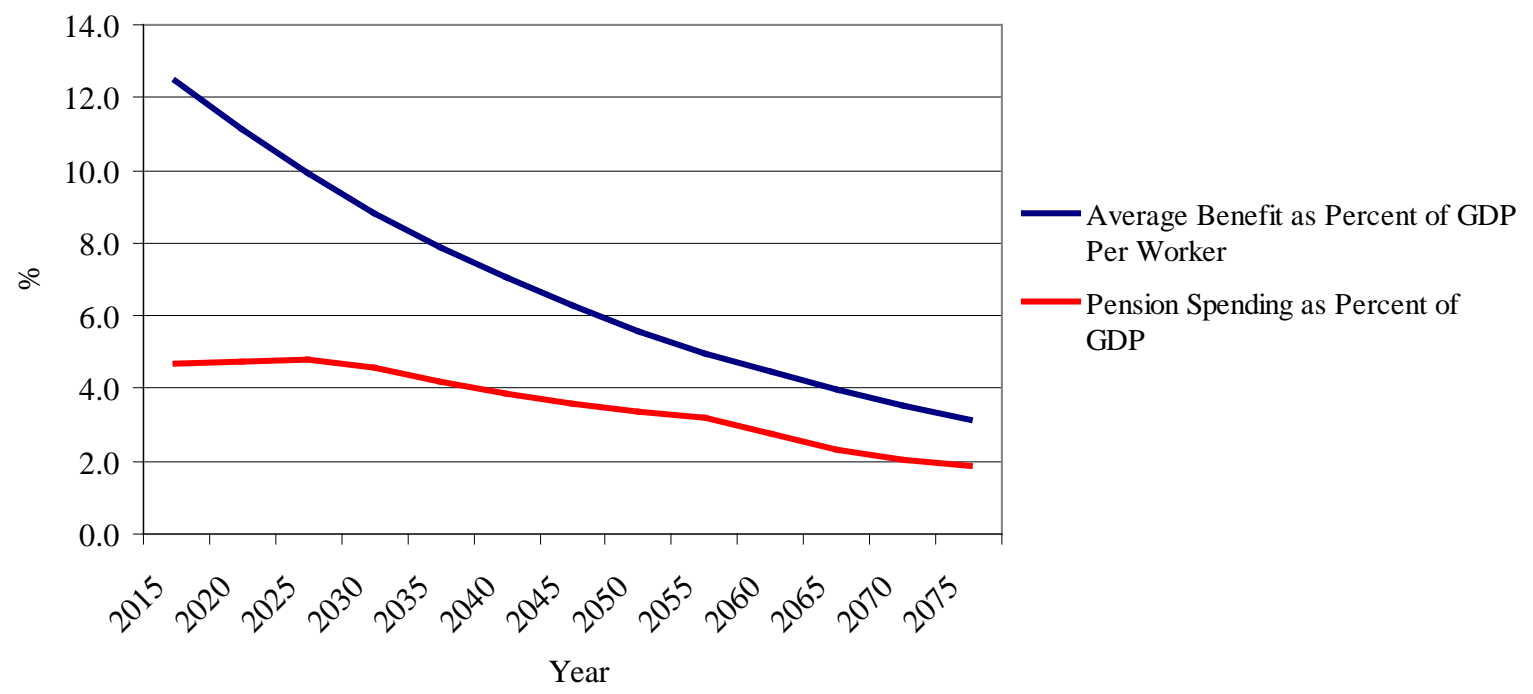

Source: Authors' calculations.

Figure 10. Changes in Retirement Ages, Relative to Baseline: Average Benefit as Percent of GDP Per Worker, Basic Pension Spending, Percent of GDP, 2015 - 2075

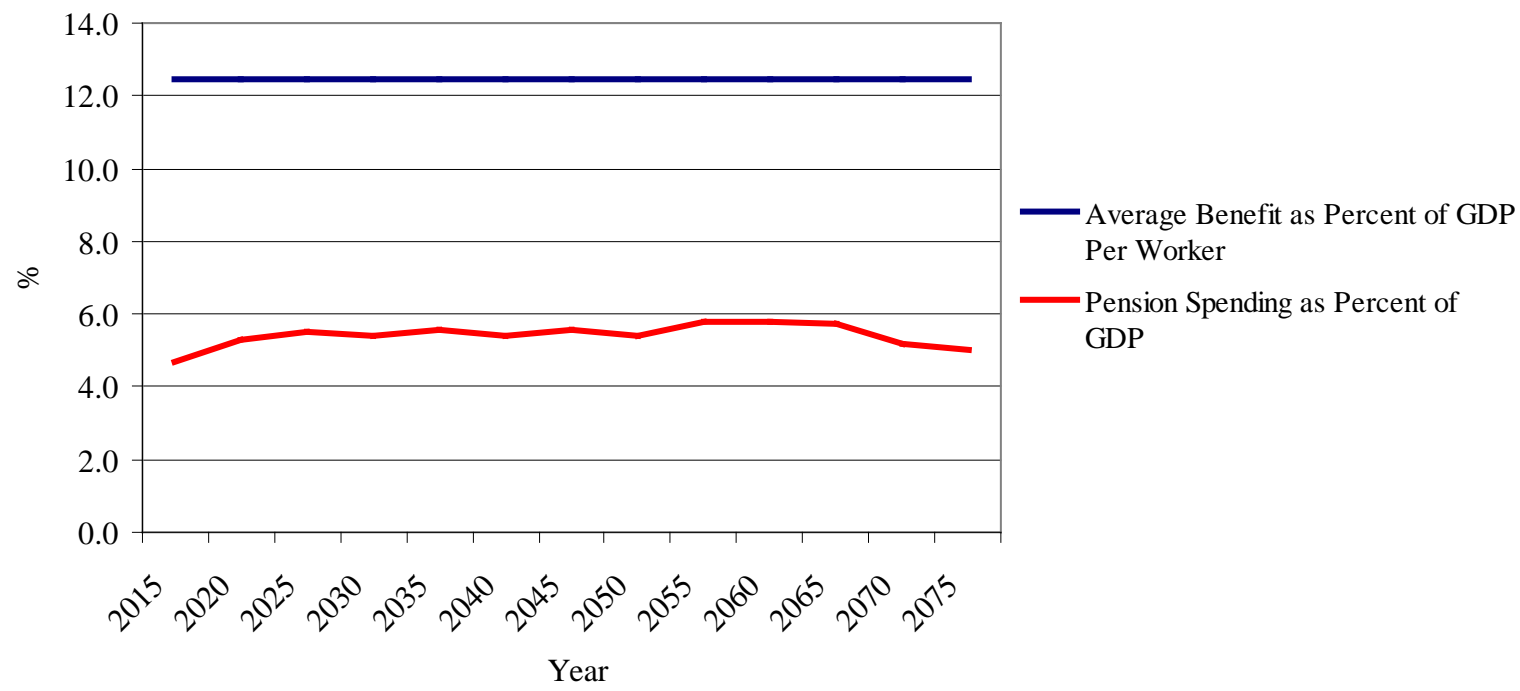

Source: Authors’ calculations. 
Figure 11. Changes in Retirement Ages, Relative to Baseline: Ratio of Pensioners to Working Age Population, Beneficiaries per Population 60+, 2015 - 2075

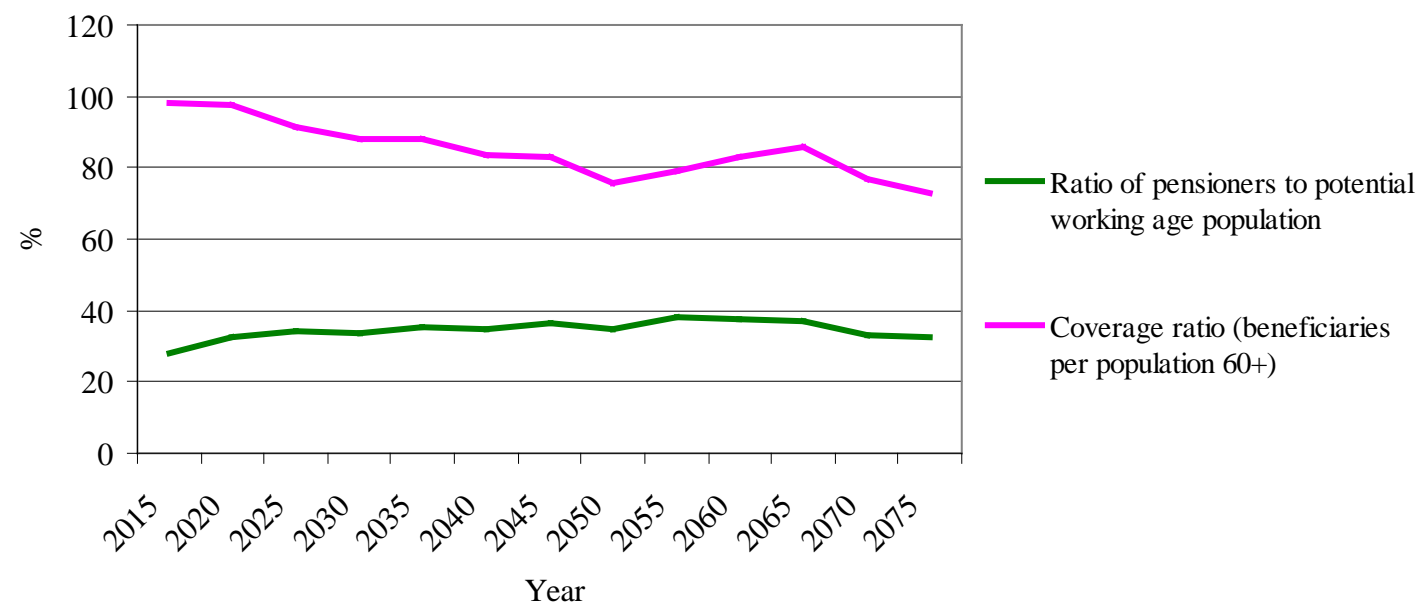

Source: Authors' calculations.

Figure 12. Reducing the Generosity of Benefits by Means Testing, Relative to Baseline: Beneficiaries per Population 60 Years and Over, 2015 - 2075

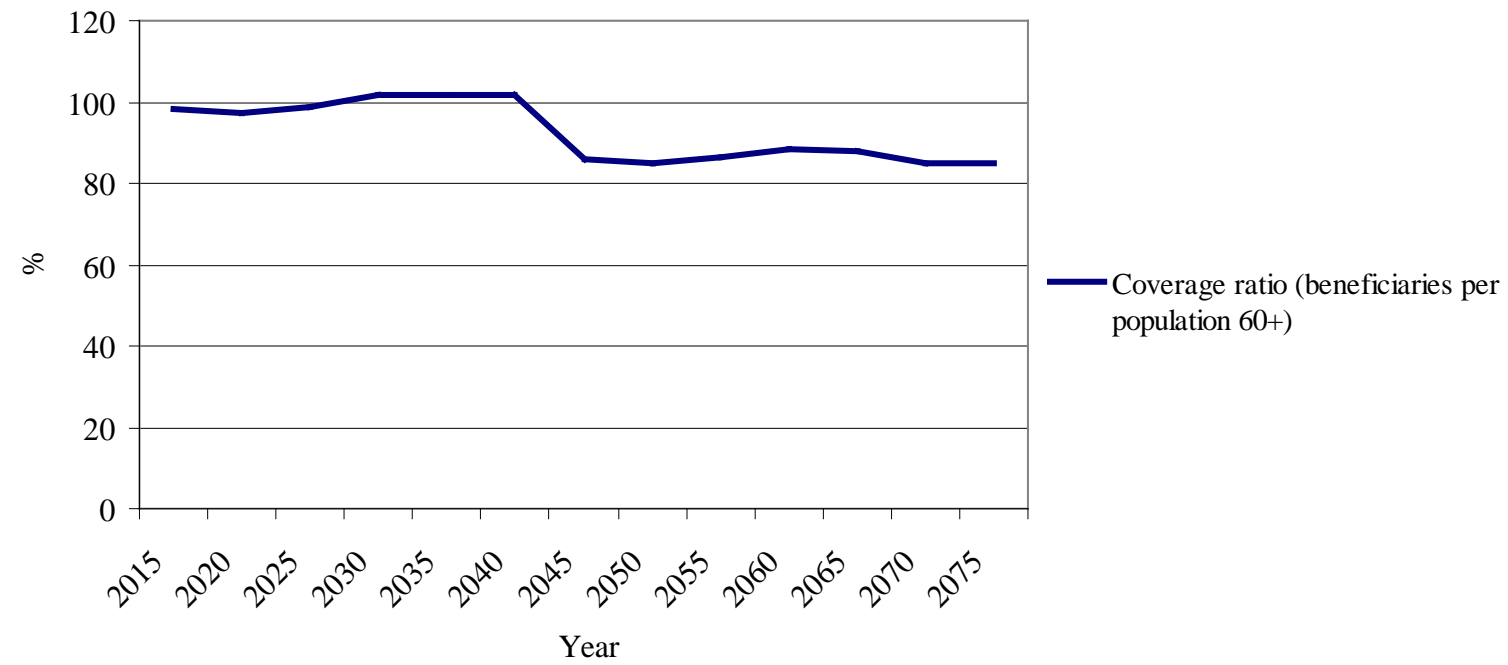

Source: Authors' calculations. 
Figure 13. Reducing the Generosity of Benefits by Means Testing, Relative to Baseline: Average Benefit as Percent of GDP per Worker, Basic Pension Spending, Percent of GDP, $2015-2075$

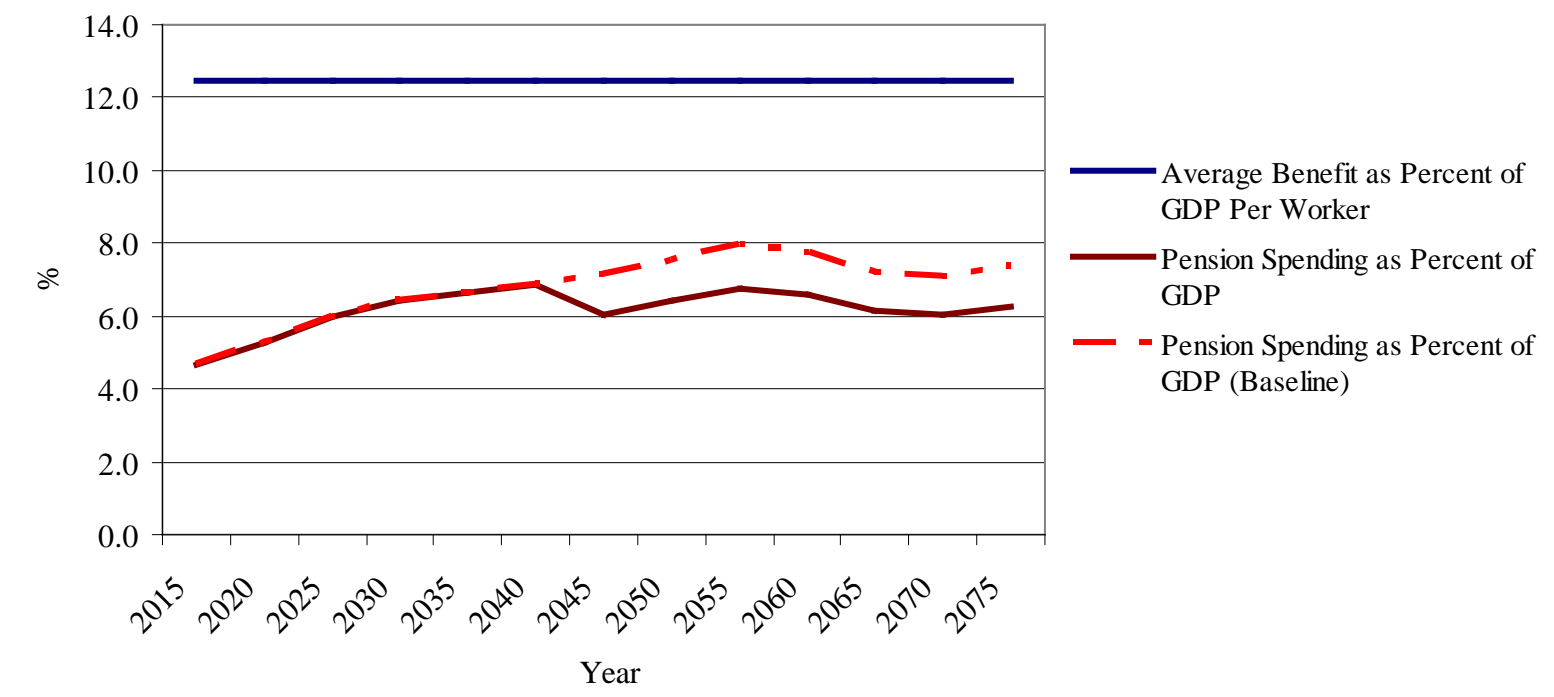

Source: Authors' calculations.

Figure 14. Simultaneous Reforms. Increasing Retirement Ages and Reducing the Generosity of Benefits by Means Testing: Average Benefit as Percent of GDP Per Worker, Basic Pension Spending, Percent of GDP, 2015 - 2075

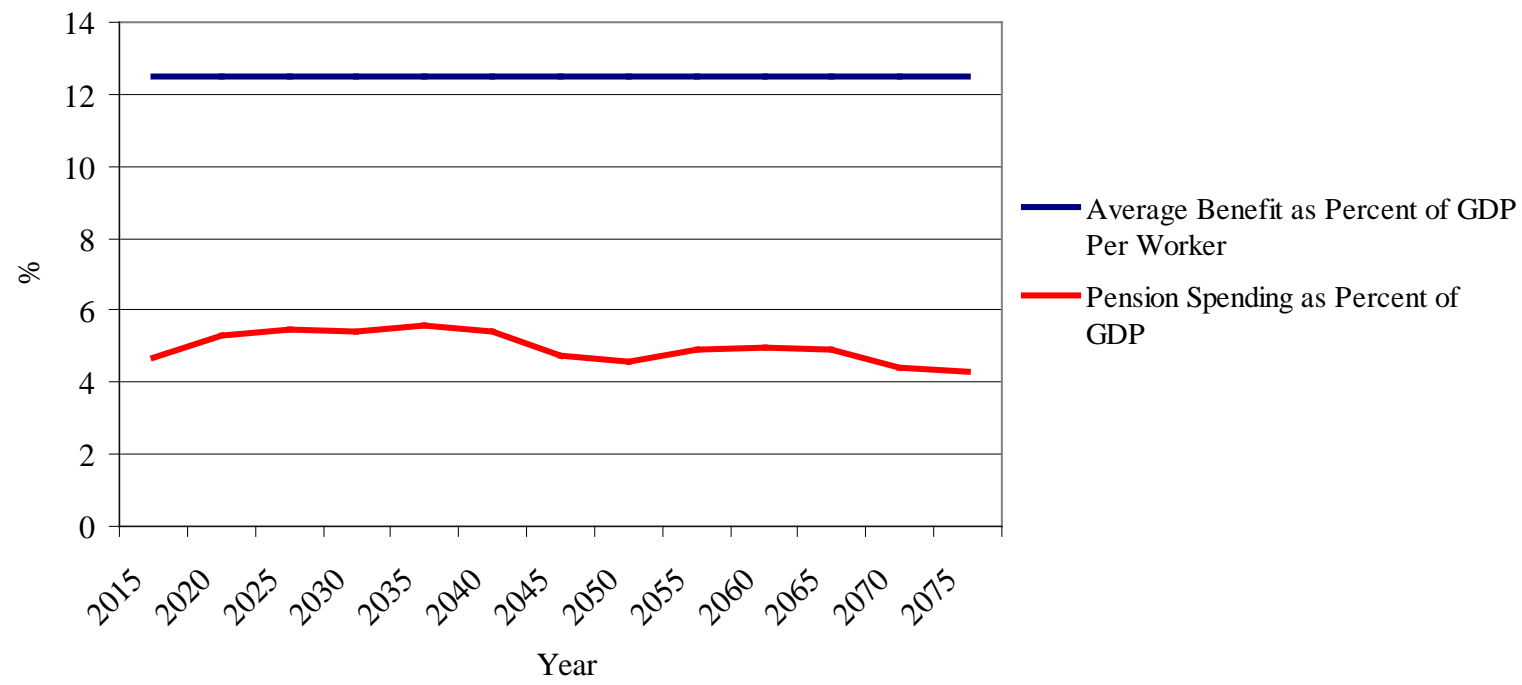

Source: Authors' calculations. 


\section{RECENT WORKING PAPERS FROM THE CENTER FOR RETIREMENT RESEARCH AT BOSTON COLLEGE}

The Transition from Defined Benefit to Defined Contribution Pensions: Does It Influence Elderly Poverty?

Natalia S. Orlova, Matthew S. Rutledge, and April Yanyuan Wu, July 2015

Will the Average Retirement Age Continue to Increase?

Matthew S. Rutledge, Christopher M. Gillis, and Anthony Webb, July 2015

The Role of Occupations in Differentiating Health Trajectories in Later Life

Michal Engelman and Heide Jackson, University of Wisconsin-Madison, July 2015

The Relationship Between Automatic Enrollment and DC Plan Contributions: Evidence from a National Survey of Older Workers

Barbara A. Butrica and Nadia S. Karamcheva, July 2015

Evidence of Increasing Differential Mortality: A Comparison of the HRS and SIPP Barry P. Bosworth and Kan Zhang, July 2015

Slowed or Sidelined? The Effect of "Normal” Cognitive Decline on Job Performance Among the Elderly

Anek Belbase, Mashfiqur R. Khan, Alicia H. Munnell, and Anthony Webb, June 2015

Does Social Security Continue to Favor Couples?

Nadia S. Karamcheva, April Yanyuan Wu, and Alicia H. Munnell, June 2015

Sources of Increasing Differential Mortality Among the Aged by Socioeconomic Status Barry P. Bosworth, Gary Burtless, and Kan Zhang, June 2015

Do Retired Americans Annuitize Too Little? Trends in the Share of Annuitized Income Barry P. Bosworth, Gary Burtless, and Mattan Alalouf, June 2015

Impact of the Financial Crisis on Long-Term Growth

Barry P. Bosworth, June 2015

Post-War Trends in Labor Income in the Social Security Earnings Records Gary Burtless and Kan Zhang, June 2015

Improving Employees' Life and Disability Insurance Benefit Decisions: Results of an Employer Survey

Anek Belbase, Norma B. Coe, and Matthew S. Rutledge, June 2015

Overcoming Barriers to Life Insurance Coverage: A Behavioral Approach

Anek Belbase, Norma B. Coe, and April Yanyuan Wu, June 2015

All working papers are available on the Center for Retirement Research website (http://crr.bc.edu) and can be requested by e-mail (crr@bc.edu) or phone (617-552-1762). 